\title{
STUDENT USE OF THE INTERNET: AN EXTENSION OF TAM IN TECHNICAL \& VOCATIONAL INSTITUTIONS IN BRUNEI DARUSSALAM
}

\author{
Afzaal H. Seyal+ \\ Mohd. Noah Abd. Rahman \\ +E-mail: ahseyal@itb.edu.bn \\ Fax: 673-2-249036 \\ Department of Computing and Information Systems, \\ Institute of Technology \\ Brunei, Tungku Link, BSB, BE 1410 \\ Brunei Darussalam.
}

\begin{abstract}
In the educational setting, the Internet is profiteering among academics and students. In fact, this has changed the functioning of the educational establishments. However, the success of use of the Internet is largely dependent upon the user's behaviour that in turn affects their attitudes. Even when the formidable opportunities exist for the deployment of technology, adverse attitude can inhibit the use.

Keeping this in view, survey of 266 students of four technical and vocational colleges was conducted to study the attitudes of the students toward the use of the Internet. The present study develop a normative model by using Davis's Technology Acceptance Model (TAM) and validates two specific attitudinal variables; perceived usefulness and perceived ease of use that are hypothesized to be fundamental determinants of the attitude that in turn predict the students' use of the Internet. By adding external variables such as; demographics, task characteristics, computer exposure, and institutional support further test the parsimony of the model. A Structural Equation modelling techniques is used to validate the model.

The study has confirmed that majority of the students $(85 \%)$ are using the Internet. In the final model the external variables do contribute towards both of belief parts: perceived ease of use and perceived usefulness that further affects the attitude of the students in predicting the Internet usage.
\end{abstract}

Keywords: Internet usage, technology adoption model, technical \& vocational students, structural equation model (SEM).

\section{INTRODUCTION}

The use of the Internet for business purposes in developed countries has become widespread over the past twenty years (Soh et al. 1997). It has become a vital tool for survival for various small businesses to compete with larger organizations (Kaplan et al. 1997). This manifold increase has not only brought a revolution in the business world but has also made the Internet as a favorite research topic among the researchers. With globalization the businesses are becoming competitive everyday and similarly the demand for resourceful, skillful and knowledge workers are increasing. In order to cope with the industry demand, educational institutions have to develop a new learning culture and to radically shift their existing resources of teaching to the new technology based curriculum. The use of the Internet among educational setting is gaining threshold popularity with the large number of academics and students are getting the benefits of the Internet technologies.

Given the opportunities and benefits that the Internet can provide the usage is still limited to infant stage. Besides countless promises of the technology, empirical research on the adoption and use of the Internet is relatively sparse. Most of the prior research in this discipline has predicted the user behavior based upon the data collected in the United States and Europe. For example, in USA by 1995 more than 40 states provided public educators with some level of Internet access (Doty, 1995). From the period of 1994-1995, access to the Internet from US public schools has increased from 35\% to 50\% (Heaviside, et al. 1995).

Comparatively, less has been researched on the adoption, diffusion and impact of the Internet among educational settings. No doubt, the Internet is permeating professional life and is being promoted as the future way of information transfer. However, we believe that academic institutions are expected to be in the forefront of applications of new technologies. Previously, the studies on the Internet were undertaken among academics and students of the universities. Little is however, researched about the use of the Internet among the academics of the technical colleges. It is argued that task characteristics, level and skill of computer experience may differ from their counterpart in the universities. This difference may have an impact on the successful use of the Internet among the technical institutions. This aspect was not addressed by the prior studies and hence there is a need to investigate this aspect into new geographical environments. As mentioned, a majority of studies were undertaken in the Western countries. However, very little has been researched in the Asia-Pacific countries. In addition, all these studies have a number of weaknesses. They are based upon single institution survey and a complete picture of the potential users, therefore cannot be analysed. In the present study, an attempt is made to cover the students of technical colleges at large to bring the broader perspective of the Internet use among the learners and to make the study different from the 
previous studies. In addition, this study has used a structural equation modelling techniques to test the hypothesized model that was missing in the prior studied.

Thus the result of these prior studies might not be applicable to a small but technologically emerging country like Brunei Darussalam. The country is culturally different not only from those of the western world but also from several of the Asia-Pacific countries. Brunei Darussalam is a small sultanate located on the northwest coast of Borneo island. Strategically located between the two technological hubs i.e., Singapore and Malaysia. It has a total population of nearly 0.3 million (Brunei Statistical Year Book, 1999) with main economic activity dominated by the oil and gas sector. The country had gross domestic product per capita was B \$ $23,865$ (US $\$ 1=1.70)$ in 1999. The government has conceived an IT vision and has taken a range of measures to improve IT infrastructure and the Internet business environment in the country. Realizing the limitation as to the size of the domestic market, Brunei business environment is determined to utilize the Internet as a major development tool.

In the educational side, currently, two engineering colleges, one vocational college and one technical institute were established to produce technologically oriented professionals at various levels. No doubt, Brunei is technologically oriented country with impressive IT infrastructure, however, the utilization of the various technological elements are mainly dominated by cultural and belief systems of the users. In the absence of extensive research it is difficult to find out the root cause of this under utilization. So keeping in view the users' aspect of utilization, the study was undertaken to collect empirical evidences of the Internet usage among the students of technical colleges in Brunei Darussalam.

\section{Objective of the Study}

The central theme of this study is to examine the student use of the Internet and this has been further classified into two sub-sections:

(a) To assess the students' current level of the Internet use and to identify the factors contributing toward the use.

(b) To test the hypothesized model by using structural equation models and to propose a model that have a greater parsim

\section{REVIEW OF TECHNOLOGY ACCEPTANCE MODELS}

The Internet use among educational settings is the area least researched comparative to the other segments of the users. A variety of factors may have influenced the limited use. The success of the Internet use however, is a multi-dimensional issue that requires the cooperation and commitment from all participants. The research on the Internet in fact is the extension of previous researches on technology diffusion, IT adoption and utilization. The studies were undertaken to develop various models. MIS researchers have used different models over the last two decades as a base for studying the information systems acceptance, adoption and usage.

In earlier work, Triandis (1971) argued that behavior is determined by what people would like to do (attitudes) what they think they should do (social norms) what they have usually done (habits) and by the expected consequences of their behavior. He suggested that attitudes involve cognitive, affective, and behavioral components. The cognitive component of attitudes involves belief. Thus attitudes involve what people believe (cognitive), feel (affective), and how they behave (behavioral) toward an object that can be a computer at early stage and later on can be substituted for information technology. The Triandis's theory has provided a base for conducting attitudinal studies.

However, researchers in the later stages have proposed several other models based upon innovation diffusion theory (Rogers, 1995), the Theory of Reasoned Action (TRA) purported by Ajzen \& Fishbein (1980), and the Technology Acceptance Model (TAM) by Davis (1989). Of these models the TAM has most widely used model to predict computer-usage behavior with generally providing determinants of technology acceptance that would help explaining user behavior towards the information technology usage. TAM has also been shown to demonstrate good predictive validity (Szanja, 1994). However, one of the constraints that was not undertaken by the TAM was the ignorance of external factors whereas, later researches has provided us with several of external variables that have an influence on the usage behavior (Pijpers et al. 2001). Agarwal and Prasad, (1997) have further suggested that external variables are the only channels for influencing behavior as the intermediate and dependant variables in TAM are hypothesized to be an internal psychological process. TAM asserts that actual use of system is determined by behavioral intentions to use and this in turn is related to attitude towards using the system. Davis, (1989) while proposing his model further asserted that influence of external behavior is mediated through user belief and attitude. Belief related to an action where as, attitude 
is purely affective that relates to positive and negative feelings about performing the behavior. The belief segments that determine the attitude are perceived ease of use (PEOU) and perceived usefulness (PU).

The TAM has been widely studied in Information Systems research as an explanation of the use of IS across information systems types and nationalities and found significant cross-cultural difference (Gefen and Straub, 1997). In a recent review, Saga and Zmud, (1993) identified twenty empirical studies that aimed at exploring the factors that determine IT acceptance. Among these twenty studies, TAM originally proposed by Davis is arguably one of the most cited. Table 1 provides us with a detail of empirical studies based on TAM. In fact, all these studies have focused primarily on the TAM model in predicting the user intentions towards information technology.

The literature tends to fall into a number of categories in the educational setting. Most of the past studies were confined to the schoolteacher's usage of the e-mail. It was undertaken at the level of adoption and utilization of the technological innovation. Songan and Noor (1999) have studied the students' use of the Internet. Doyle and Ponder (1977) and Cuban (1986) found that positive relationship existed between acceptance of innovation when they seem to be compatible with the previously established value, norms, procedure and facility. Brown and McIntyre (1982) found that perceived practicality and cost of implementing an innovation were crucial to utilization. The large part of these studies deals with its development and general definition and terms relating to the facilities that the Internet provides (Gould, 1995 and Stix, 1994).

Palvi et al. (1995) studied both academic staff and undergraduate students population in one of the Singaporean universities and indicated a higher level of awareness between both groups, however, the use was primarily limited to e-mail. Survey has further indicated that majority of the respondents felt that undergraduate students must be Internet literate. Songan and Noor (1999) studied Internet utilization among students at an institution of higher learning in Malaysia and found that gender and faculty's type have no impact on the Internet utilization. Where as, factors such as relative advantage, compatibility, complexity, importance and interactivity affect the use of Internet.

Table 1 Empirical studies testing TAM

\begin{tabular}{|l|l|l|}
\hline Researchers & Year & Technology features studied \\
\hline Davis & 1989 & E-mail and graphic software Chart Master \\
\hline Davis et al. & 1989 & Word Processor \& Text-editor \\
\hline Thompson et al. & 1991 & PC \\
\hline Mathieson & 1991 & Spreadsheet \\
\hline Sproull & 1991 & E-mail \\
\hline Rice and Aydin & 1991 & E-mail \\
\hline Adams et al. & 1992 & Voice-mail and WP \\
\hline Lu \& Gustafson & 1994 & Computerized Support System \\
\hline Markus & 1994 & E-mail \\
\hline Straub et al. & 1995 & Voice-mail \\
\hline Chin and Gopal & 1995 & Group Support System \\
\hline Igbaria et al. & 1995 & Computer Usage \\
\hline Szanja & 1996 & Data-base management system \\
\hline Straub et al. & 1997 & A Cross-cultural studies of e-mail use \\
\hline Gefen \& Straub & 1997 & Perception \& use of E-mail \\
\hline Lou et al. & 2000 & Groupware acceptance \\
\hline Yang \& Choi & 2001 & Office-automation and Internet use \\
\hline Veiga et al. & 2001 & IT acceptance \\
\hline Pijpers et al. & 2001 & Executive Information Systems \\
\hline Seyal et al. & 2002 & Academic use of Internet \\
\hline & & \\
\hline
\end{tabular}

In Australia, Spennermann (1997) surveyed student attitudes towards use of e-mail at one of the Australian universities and significant differences in positive usage were noticed between external as well as internal students. The internal students are more likely to use e-mail as a method of communication with their academics.

Alscili (2000) has researched that despite the widespread use of the Internet, there are no well-organized studies providing information about its use as a research tool and in classroom instruction at one school of Information Systems in USA.

The studies cited above have also identified a variety of factors that affect the users' attitudes of Internet among academic work-settings. Some of the frequently reported factors such as computer exposure include ownership of a PC, and PC experience, task characteristics. PC experience was given considerable attention from some authors in addition to two attitudinal factors PU and PEOU. 
Although the review of the literature has provided a base for the choice of the variables to be included in this study, however, final selection of the study variables are in fact based upon several others Brunei-based studies in IS/IT (Rahim et al. 2000; Seyal et al. 2000, 2001). Giving the ongoing importance to the use of the Internet the selection of the variables are also in line with the objective to test a parsimonious predictive model that is multi-dimensional and posits multi-items variables: demographical variables, PC exposure, task characteristics, institutional support, belief and attitudinal aspect. By testing all the factors together in one model, we are able to investigate their relative contributions to the student use of the Internet. This model can be generalized to other inter-organizational information technology usage.

\section{RESEARCH MODEL}

On the basis of existing literature and of several informal discussions with the members of academic staff of technical colleges during the early stage of research design, a normative model was developed. This model provides the basis of research.

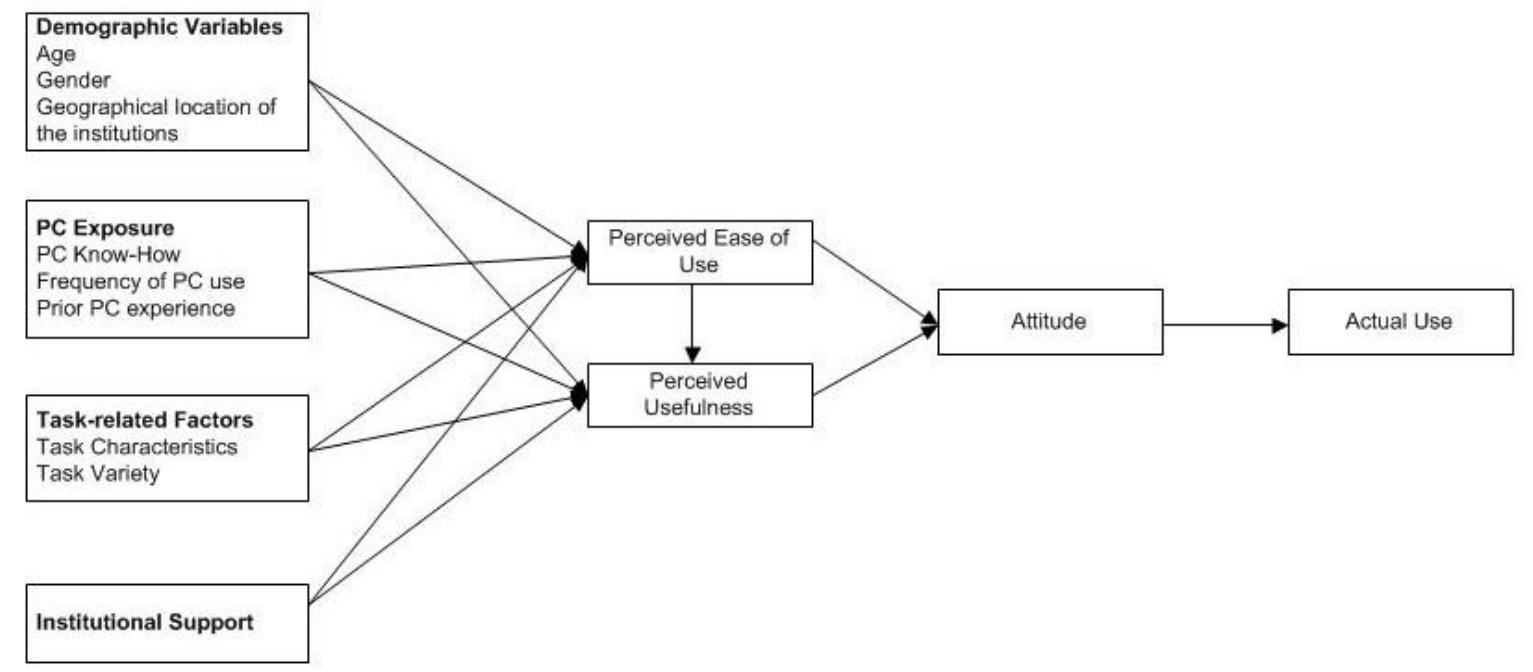

Figure 1 Theoretical Research Model (Extension of TAM)

The normative model as depicted in Figure 1 relates independent (externals) and dependent variables with the intervening or intermediate (perceived ease of use, perceived usefulness and attitude) variables. The relationship as shown in the model is associative rather than casual in nature. In this study, the student actual use of the Internet is the dependent variable, while the normative model ties together four constructs having nine independent variables. Justification for inclusion of each independent variable and to set up hypotheses in the model is presented in Table 2. 


\begin{tabular}{|c|c|c|c|}
\hline Constructs & No & Prior Relationship Tested & Source of selection \\
\hline \multicolumn{4}{|l|}{ A. Demographics } \\
\hline Age & HA1 & Negative & Pijpers et al. 2001 \\
\hline Gender & HA2 & Men more positive & $\begin{array}{l}\text { Songan \& Noor, 1999; Gefen \& } \\
\text { Straub, 1997; Igbaria et al. 1995; } \\
\text { Pijpers et al. } 2001\end{array}$ \\
\hline Geographical location & HA3 & $\begin{array}{l}\text { New variable studied positive in } \\
\text { one studies \& neutral with two } \\
\text { others studies }\end{array}$ & $\begin{array}{l}\text { Rahim et al, 2000; Seyal at al. } 2000 \text {, } \\
2002\end{array}$ \\
\hline \multicolumn{4}{|l|}{ B. PC Exposure } \\
\hline PC ownership & HB1 & $\begin{array}{l}\text { Negative } \\
\text { Positive }\end{array}$ & $\begin{array}{l}\text { Seyal et al. } 2002 \\
\text { Rahim et al. 2000; Seyal et al. } 2000\end{array}$ \\
\hline PC know how & HB2 & Positive & Igbaria et al. 1995 \\
\hline Frequency of use PC & HB3 & Positive & $\begin{array}{l}\text { Igbaria et al. 1995; Igbaria \& } \\
\text { Chakraborti } 1990\end{array}$ \\
\hline PC experience & HB4 & Positive & $\begin{array}{l}\text { Igbaria \& Chakraborti, 1990; Igbaria, } \\
\text { 1992; Aljabri \& Al-Khaldi, } 1997\end{array}$ \\
\hline \multicolumn{4}{|l|}{ C. Task-Related } \\
\hline Task characteristics & $\mathrm{HC1}$ & $\begin{array}{l}\text { Positive } \\
\text { Negative }\end{array}$ & $\begin{array}{l}\text { Kwon \& Zmud, 1987; Yverbaum, } \\
1988 \text { Igbaria et al. } 1995 \\
\text { Seyal et al. } 2002\end{array}$ \\
\hline Task Variety & $\mathrm{HC} 2$ & Positive & $\begin{array}{l}\text { Ghani, 1992; Goodhue \& Thompson, } \\
1995\end{array}$ \\
\hline D. Institutional support & HD1 & Positive & Pijpers et al. 2001 \\
\hline \multicolumn{4}{|l|}{ E. Intervening Variables } \\
\hline Perceived ease of use & HE1 & Positive with PU & Goodwin, 1987; Igbaria, 1992 \\
\hline Perceived Ease of use & HE2 & Positive with attitude to use & $\begin{array}{l}\text { Davis et al. 1989; Bajaj \& Nidumolu, } \\
\text { 1998; Pijpers et al. } 2001\end{array}$ \\
\hline Perceived Usefulness & HE3 & Positive with attitude to use & $\begin{array}{l}\text { Thompson et al. 1991; Igbaria \& } \\
\text { Tracker, 1994; Pijpers et al. } 2001\end{array}$ \\
\hline Attitude towards use & HE4 & Positive with actual use & Bajaj \& Nidumolu, 1998 \\
\hline
\end{tabular}

The prior literature is full of studies that has used TAM and related it to numerous external variables. Interestingly no consistency has been noticed in making choice of external variables. Pijpers et al. (2001) have used twenty-seven variables and grouped them into demographical, organizational task related, characteristics of IT resources and attitudinal variables that measure PU, PEOU and affective attitudes segment. As mentioned earlier, the selection of external variables for the present study is exclusively based upon the prior research in technical colleges of Brunei Darussalam.

\section{RESEARCH METHODOLOGY}

\section{Design of Instrument}

The inclusion of the various multi-item, multi-dimensional constructs in all four parts of the instrument is based upon existing constructs taken from previous researches (Davis, 1989; Igbaria and Chakraborti, 1990; Igbaria and Tan, 1997; Turner and Zheng, 1998; Harris, 1999). Construct measuring computer experience is adapted from Igbaria (1992). Table 3 provides the detail of items measured along with the mean and corrected-item total. The construct measuring attitudes part is adapted from Bijaj and Nidumolu, (1998). It is commonly believed that use of the Internet is a multi-dimensional construct that measures the various types of the Internet use. As such to determine the use of the Internet is one of the objectives of this study, therefore Table 4 provides the detail of various types of usage along with their mean and standard deviation. Multipleact indicators measure the dependent variable; the use of the Internet. Likewise computer experience, the Internet use was measured as overall indexes of total number of categories the respondents reported the use. Construct measuring PU and PEOU intervening variables asks the respondents for twenty-six statements adapted from Davis, (1989). 
Table 3 Computer Experience

\begin{tabular}{|c|c|c|c|}
\hline Items & $\begin{array}{l}\text { Responses } \\
\text { Above } \\
\text { Average }\end{array}$ & $\begin{array}{l}\text { Mean } \\
\text { Experience }\end{array}$ & $\begin{array}{l}\text { Correct } \\
\text { ed-item } \\
\text { Total }\end{array}$ \\
\hline Using computer packages such as spreadsheet and word processing & $56 \%$ & 3.51 & .34 \\
\hline Using application languages such as, SQL, Oracle, dBase $1 \mathrm{~V}$, Access & $12.5 \%$ & 1.95 & .61 \\
\hline Using decision support packages such as, financial, statistical or graphical & $10 \%$ & 1.96 & .66 \\
\hline Use of programming language such as, Cobol, Fortran, Pascal, C, C++ & $19 \%$ & 2.19 & 67 \\
\hline Participation in the non-technical design of computer system & $13 \%$ & 1.76 & .71 \\
\hline Participation in the technical design of computer system & $13 \%$ & 1.79 & .67 \\
\hline
\end{tabular}

\section{Population and Sample size}

There are 4 technical colleges in Brunei Darussalam that offer Trade Certificate, National diploma (ND) and Higher National diploma (HND) programs in various disciplines. The target population was the students of these technical colleges. The total numbers of students in all these four colleges were reported to be 1266 (Anonymous, 1998). The questionnaire was therefore sent to one third of the students (422) based upon the stratified random sampling techniques and by fulfilling criteria (Zikmund, 1984) Out of these total 266 responses were received to further test the model.

Table 4 Internet Use

\begin{tabular}{|l|l|l|}
\hline \multicolumn{1}{|c|}{ Items } & Mean & Std.Dev \\
\hline To gather student material & 3.71 & 1.23 \\
\hline To gather teaching aids & 3.61 & 1.13 \\
\hline To perform learner activities & 2.52 & 1.21 \\
\hline To enhance general knowledge & 3.46 & 1.13 \\
\hline To keep informed of interesting developments & 3.20 & 1.36 \\
\hline To keep abreast of exhibitions/trade shows and conferences & 2.30 & 1.34 \\
\hline To subscribe to scholarly users group & 2.09 & 1.16 \\
\hline For recreational use & 2.83 & 1.41 \\
\hline
\end{tabular}

\section{Instrument validation and reliability}

There are several types of validity measure that include the face validity and construct validity. Campbell and Fiske (1959) proposed two types of construct validity: convergent and discriminant validity. In order to establish face validity, an initial version of the instrument was pre-tested using several students selected randomly from two colleges located in close proximity of the authors' work place. The participants were asked to comment on the format and appropriateness of questions, and to suggest any items that they believed should be included in the instrument. In view of their suggestions, several amendments were incorporated into the instrument, with the inclusion of some new variables that has greatly improved clarity. The derived instrument was then tested for reliability. In line with our research model, as mentioned earlier, part of the instrument that measures the intervening variables PU and PEOU consists of 26 items is adapted after Davis (1989) The original version was used to test e-mail and a graphic software Chart-master, however, all the items were reworded for this study. These statements were passed through purification and elimination as proposed by Churchill, (1979). 6-items were taken away because of their lowest corrected-item correlation (< $.40)$. Then the remaining 20-items were tested for exploratory factor analysis that has resulted for 2-factors solution. The remaining 20-items, provides with two factors solution (PU and PEOU) in Table-5. 
Table-5 Varimax rotated factor loading and eigenvalues with variance explained

\begin{tabular}{|l|l|l|l|}
\hline Items No & Items description & Factor 1 & Factor \\
\hline Att-1 & My job would be difficult to perform without the Internet & \\
\hline Att-2 & Use of Internet gives me a great control over my job & .80 & \\
\hline Att-3 & Use of Internet improves my job performance & .82 & \\
\hline Att-4 & Interacting with Internet is confusing & .79 & \\
\hline Att-5 & I make frequent errors when using the Internet & & .82 \\
\hline Att-6 & Interacting with the Internet is frustrating & & .79 \\
\hline Att-7 & The Internet system addresses my job related needs & .78 \\
\hline Att-8 & Use of Internet saves time & .70 & \\
\hline Att-9 & The Internet enables me to accomplish task more quickly & .76 & \\
\hline Att-10 & I need help when I use the Internet & .82 & .65 \\
\hline Att-12 & Overall I find Internet useful in my job & .69 & \\
\hline Att-13 & I find it easy to get Internet to do what I want to do & .79 & \\
\hline Att-14 & $\begin{array}{l}\text { Use of the Internet allows more to accomplish more work than would otherwise } \\
\text { be possible }\end{array}$ & .83 & \\
\hline Att-15 & Use of the Internet reduces the time I spend on unproductive activities & .73 & \\
\hline Att-16 & Use of Internet enhances my effectiveness on the job & .77 & \\
\hline Att-19 & My interaction with the Internet is easy for me to understand & .80 & \\
\hline Att-20 & It is easy for me to remember how to perform tasks using the Internet & .85 & \\
\hline Att-22 & Use of the Internet improves the quality of my work & .85 & \\
\hline Att-23 & Use of the Internet increases my productivity & .84 & \\
\hline Att-24 & Use of the Internet makes it easier to do my job & .83 & \\
\hline & & $\mathbf{1 5 . 5 1}$ & $\mathbf{1 . 6 8}$ \\
\hline & & $\mathbf{6 4 \%}$ & $\mathbf{1 7 \%}$ \\
\hline
\end{tabular}

Note: Factor 1 refers to perceived usefulness and Factor 2 refers to perceived ease of use.

Both factors explain $81 \%$ of the variance. The Kaiser Meyer-Olkin measure of sampling adequacy of .85 suggests that data is suitable for factor analysis. Factor analysis has further revealed the construct validity as such all the items have highest factor loading (.50 or above) and load on two factors. The factorial validity further supports construct validity. The derived instrument was then tested for discriminant validity. There are several approaches to apply discriminant validity. The term refers to the extent to which a concept differs from others (Campell and Fiske, 1959). One way of determining this for a construct to see if it correlates with other constructs is less than its Cronbach alpha coefficient (Gaski and Nevin, 1985). Bajaj and Nidumolu, (1998) has used the same technique in one of their attitudinal-based study. Table 6 reflects the comparison of the Cronbach alphas with the correlations and found to be true. 
Table 6 Correlation between the various constructs

\begin{tabular}{|c|c|c|c|c|c|c|c|c|c|c|c|}
\hline Constructs & Mean & $\begin{array}{l}\text { Std } \\
\text { Dev }\end{array}$ & $\begin{array}{l}\text { Interna } \\
\text { I } \\
\text { reliabili } \\
\text { ty (.70 } \\
\text { or } \\
\text { above) }\end{array}$ & 1 & 2 & 3 & 4 & 5 & 6 & 7 & 8 \\
\hline 1.PC Experience & 2.15 & .77 & .83 & 1.00 & & & & & & & \\
\hline 2.Task Characteristics & 3.15 & .86 & .89 & $\begin{array}{l}- \\
.238^{*} \\
*\end{array}$ & 1.00 & & & & & & \\
\hline 3.Task Variety & 2.95 & .84 & .90 & -.09 & .517 & 1.00 & & & & & \\
\hline 4. Internet Use & 2.95 & .80 & .92 & $\begin{array}{l}.214^{*} \\
*\end{array}$ & $.302 *$ & $\begin{array}{l}- \\
.325^{*} \\
*\end{array}$ & 1.00 & & & & \\
\hline 5.Institutional Support & 2.29 & 1.00 & .92 & -.507 & -.062 & $.225^{*}$ & $\begin{array}{l}- \\
.220^{*} \\
*\end{array}$ & 1.00 & & & \\
\hline 6.Perceived Usefulness & 3.63 & .68 & 97 & -.012 & 133 & -.015 & $\begin{array}{l}.288^{*} \\
*\end{array}$ & $\begin{array}{l}- \\
.280^{*} \\
*\end{array}$ & 1.00 & & \\
\hline 7.Perceived Ease of Use & 2.87 & .80 & .83 & $\begin{array}{l}- \\
.155^{*}\end{array}$ & $\begin{array}{l}.234^{*} \\
*\end{array}$ & $\begin{array}{l}.285^{*} \\
*\end{array}$ & -.109 & $.199^{*}$ & -.056 & 1.00 & \\
\hline 8. Attitude & 3.45 & .66 & .87 & -.036 & -.049 & .042 & $.185^{*}$ & -.110 & $\begin{array}{l}.697 * \\
*\end{array}$ & $\begin{array}{l}.215^{*} \\
*\end{array}$ & $\begin{array}{l}1.0 \\
0\end{array}$ \\
\hline
\end{tabular}

Significance $* *(p<.0 .05) *(p<0.01)$

\section{ANALYSIS \& RESULTS}

266 questionnaires received were analyzed to test the research model in Fig 1 by using SPSS for descriptive analysis.

SEPATH, SEM program from STATISTICA 6.0 statistical software was used to test the relationship and to further test the parsimony of the structural model. Table 7 reflects the background profile of the students.

Structural equation model (SEM) estimates a series of separate but interdependent multiple regression equation (Stelzl, 1986). Many researchers (Joreskog and Sorborn, 1983; Kelloway, 1998) proposed a twostage process: (1) to estimate the measurement model and (2) to investigate the structural model.

\section{Measurement Model}

When studying the structural model, many researchers (Kelloway, 1998; Breckler, 1990) propose a two-stage model: (i) measurement model, (ii) investigating the structural model. Theoretically, in a measurement model an investigation into the structure between items and constructs is carried out. Normally a multi-trait, multidimensional approach is adopted. Initial screening indicated that some of the external variables are not normally distributed and are skewed. By testing the measurement model we therefore test the reliability and validity of the instrument.

\section{Structural Model}

Stelzl (1986) and Lee and Hersberger (1990) have proposed rules for generating equivalent model. In general, this involves altering the pattern of relationships or paths within the original model so as to produce an alternative model. As mentioned, single stage analysis was conducted for various sub-models (1-3). The result has indicated that the external variables had no significance at all. At the outset, demographic variables gender age and geographical location of the institution were trimmed off and than later on; PC ownership, PC use and PC knowledge were taken out. As such all these variables are either based upon dichotomous or categorical scale and the initial data analysis has revealed that these variables are very much skewed. The PC knowledge and PC use are self-reported items with possibility of response errors. So we have excluded them from our first measurement model. The first model was therefore tested for the remaining external variables with the intervening variables Perceived Usefulness and Perceived Ease of Use. Unfortunately this model has very little parsimony. 
Table 7 Background profile of the students

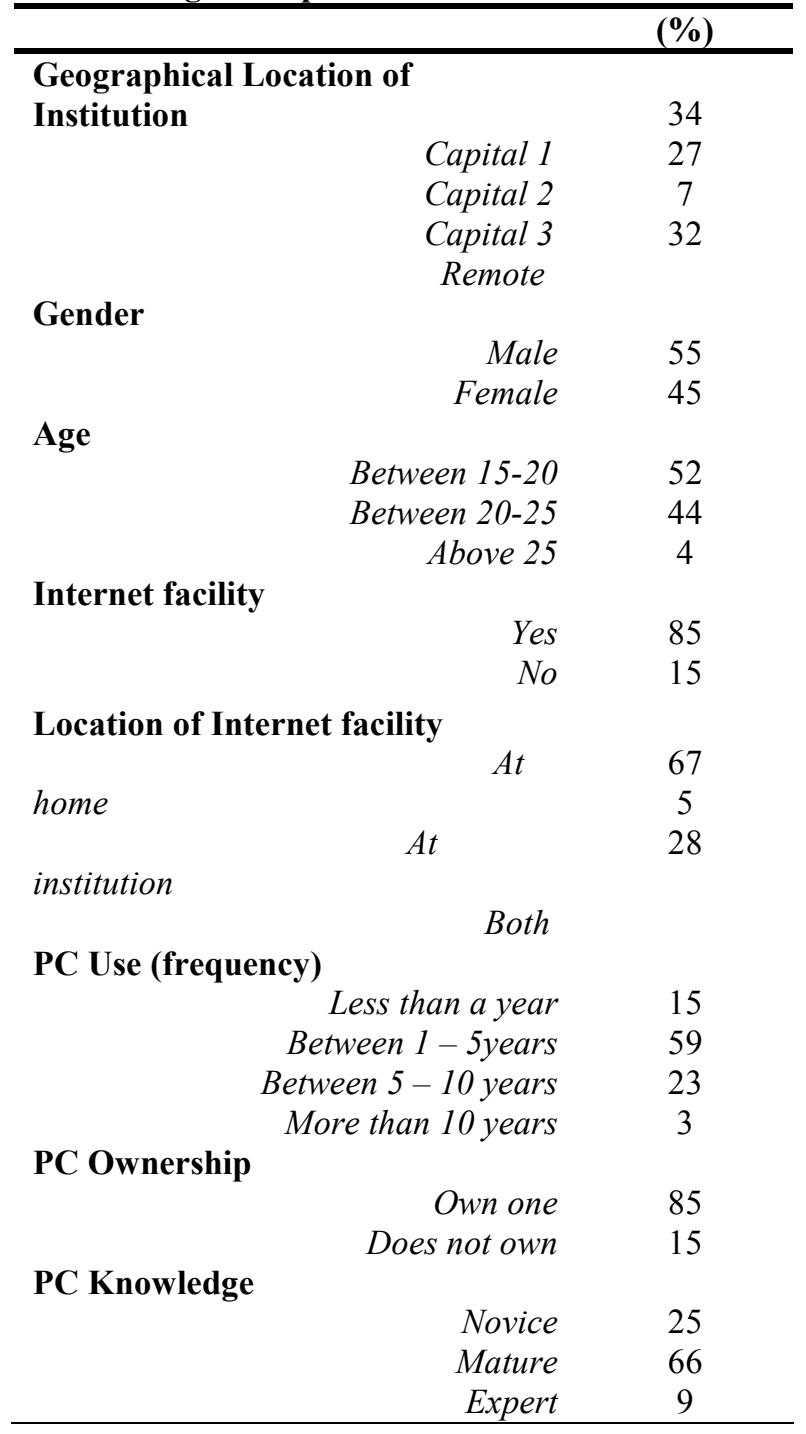

Table 8. Comparison of goodness-of-fit measures

\begin{tabular}{|l|l|l|l|l|}
\hline Goodness-of-fit measure & $\begin{array}{l}\text { Recommended } \\
\text { value }\end{array}$ & $\begin{array}{l}\text { Model } \\
\mathbf{1}\end{array}$ & $\begin{array}{l}\text { Model } \\
\mathbf{2}\end{array}$ & Model3 \\
\hline Chi-square/degree of freedom & $\leq 3.0$ & 10.7 & 8.7 & 3.2 \\
\hline Goodness-of-fit index (GFI) & $\geq .90$ & .71 & .73 & .78 \\
\hline Adjusted goodness-of-fit-index (AGFI) & $\geq .90$ & .41 & .49 & .70 \\
\hline Normed fit index (NFI) & $\geq .90$ & .42 & .25 & .83 \\
\hline Not-normed fit index (NNFI) & $\geq .90$ & .02 & .05 & .85 \\
\hline Comparative fit index (CFI) & $\geq .90$ & .47 & .24 & .87 \\
\hline Root Mean square approx (RMSEA) & .005 & .02 & .17 & .01 \\
\hline \multicolumn{1}{|c|}{$\mathbf{R}^{2}$} & & .18 & .20 & .40 \\
\hline
\end{tabular}

(*Recommended values are adapted after Kelloway, 1992)

In model 2 all the external variables such as PC exposure, Task related and institutional support were tested to determine the student's use of the Internet without the intervening variables. This model has very little support as evident from the Table 8 . It further explains the $20 \%$ of the total variations toward the use of the Internet. While assessing the parsimony of the model Falk and Miller, (1992) criteria were considered that suggests that loadings on paths between latent variables and manifest variables should be 0.55 . The PC ownership and 
PC knowledge do not meet the criteria so they were dropped out from the model. After trimming the significant path analysis between exogenous constructs (PC experience, Task characteristics, Task variety and Institutional support were studied. Table 9 below shows that a number of external variables had a significant effect on PU and PEOU and attitude. As hypothesized, PU and PEOU determine attitude toward use jointly. Although most of the prior research in TAM exhibit roughly equivalent influence on the acceptance and use of an information technology, however, in our case the path coefficients between PEOU and attitude is not very attractive although the associated $p$-value is significant, yet it is not a significant predictor of attitude. In other words, the PU mainly determines attitude. Ease of use is not perceived by the students to be related to the functionality of the Internet--i.e. Its usefulness, because it interferes with their daily routine work might be an aid to complete various assignments. Finally, attitude had a positive relationship with the use of the Internet and from Table 9 seems to be very strong. This model had a better predictive power as compared to two others with about $40 \%$ of the total variance is explained. Moreover, its chi-square/degree of freedom ratio is close to the recommended value as indicated in Table 8.

\section{DISCUSSION}

One of the objectives of this study was to identify the current level of use of the Internet among students. The study has produced interesting findings. $85 \%$ of the students have used the Internet facility. Out of them $67 \%$ are using the facility at home. The institutional resources need to be enhanced to support the increasing demand.

The second objective of this study was to develop and test a model for better parsimony. This was achieved through structural equation modeling. To our best knowledge no previous study has ever targeted the students from technical \& vocational colleges with the use of the Internet and the application of robust theoretical model. In this study the research model was used to identify key factors and relationships likely to influence the acceptance and use of the Internet. The result supports the theory that the link between the two beliefs and attitudes as well as between attitudes and actual use is strong. The study has also concluded that external variables influence usage behavior but the belief construct do not fully mediate this influence as the some of the external variables have strong paths coefficients for PU and some others have strong path coefficient for PEOU.

In the study we have used at the outset a set of uncontrollable variables such as, gender, age, geographical location of the institution and the ownership of PC and were excluded in our structural model as being very much skewed. Where as, other external variables such as; PC experience, task characteristics, task variety, institutional support are taken as controllable variables. The controllable as well as the intervening variables (PU and PEOU) are important because we believe that these have an impact on belief and behavior to further encourage the use.

The result shows that PC experience is significantly linked to the PU and not significant with PEOU. This makes sense that as such PC experience measures the students' competency and skill on PC so the ease of use does not matter at all. The findings are inline with Igbaria \& Chakraborti, (1990); Seyal et al. (2002). Similarly, the task characteristics that involve the browsing the web for various types of jobs have a significant path coefficient for both PU and PEOU with minor difference in PEOU. On the other hand, task variety plays a significant role in influencing belief toward the use of the Internet. Task variety provides an additional dimension of task characteristics. It is further supported by strong path coefficient for PU. The findings support the preposition that an individual who performs a great variety of tasks by using the Internet will become personally involved with technology that enhance the further use. The findings are in line with several prior studies (Goodhue and Thompson, 1995; Harris, 1999).

Institutional support is in fact available to only $33 \%$ of the students. Actually only two institutions at present provide this support. The aspect needs to be further examined by the relevant authorities. $67 \%$ of the students are using the Internet facility at home and the existing setup of service provider is not very cost-effective so the students may foresee this with the ease of use. As more institutional support is expected it will in turn enhance the use at later stages. This is reflected in Table 9 with strong path coefficient with the PEOU. Our findings do not fully supports Pijpers et al. 2001 who have found that organizational support enhances the actual use but not the belief part. 
Table 9. Estimates of the parameters of structural equation model 3

\begin{tabular}{|l|l|l|l|l|}
\hline Path & To & \multicolumn{5}{|c|}{ Path Coefficient } \\
\hline From & Perceived Usefulness & Perceived Ease of Use & Attitude & Use of the Internet \\
\hline & .391 & Not Significant & & \\
\hline PC Experience & .301 & .311 & & \\
\hline Task Characteristics & .763 & .572 & & \\
\hline Task Variety & .401 & .580 & & \\
\hline $\begin{array}{l}\text { Institutional } \\
\text { Support }\end{array}$ & & & .625 & \\
\hline $\begin{array}{l}\text { Perceived } \\
\text { Usefulness }\end{array}$ & & & .124 & \\
\hline $\begin{array}{l}\text { Perceived Ease of } \\
\text { Use }\end{array}$ & & & & .906 \\
\hline Attitude & & & &
\end{tabular}

(All values are significant at $p<.01$ except the one)

The findings further support the theory that the link between the two beliefs and attitudes as well as between attitude and actual use is strong but if we consider the path coefficient as a measuring parameter, the affect of perceived usefulness is more strongly believed to predict the attitude than perceived ease of use as reflected in Table 9. Several studies found that PEOU had no significant effects on intention to use the technology (Davis, 1989; Igbaria et al. 1995; Chau, 1996). This is mainly because of the fact that users are more computer literate and technologies are more user friendly and even most of the college assignments regardless of the area of study involve more and more of Web-based search, the PEOU has become less a factor in technology acceptance decision (Chau, 1996). PEOU only encourage at the more novice to try the technology features and utilities that require wide participation more useful at the early stage. Likewise, most of the previous studies, our study also found that perceived usefulness had the greater direct affects on intention to use. It further implies that students would only use the technology (Internet) if they think that technology would help them to perform the task. This further leads to develop the favorable student' attitude that eventually predict the student use of the Internet in the technical colleges of Brunei.

As such, none of the re-specified models present an ideal situation of the acceptance criteria as laid down by Kelloway,(1998). We should take precautions to accept the results. Overall, model 3 has better parsimony compared to the others with relatively better $\mathrm{R}^{2}$. As stated by Chin \& Todd (1995), we should not purely rely on model fit criterion; instead, closer attention should be paid to the predictiveness of the model and on the path coefficients. Standardized paths should be at least .20 and ideally above .30 in order to considered meaningful. Fortunately, our model 3 meets this criterion and can therefore be used to deduct the meaningful deductions.

\section{CONCLUSION}

The study has fulfilled both of the objectives of the research. We found that $85 \%$ of the students are using the Internet facility. The study provide support for the core TAM model as an adequate and parsimonious. As such TAM assumes that the influence of external variables on use is channeled through two belief segments that have impact on attitude to predict the use of the technology. This study has confirmed the TAM core model. Under the three structural equation models the third one with better parsimony have further suggested that external variables; PC experience, task characteristics, task variety, institutional support channelize the two beliefs segment PU and PEOU that directly affect the attitude and the favorable attitude predicts the students' use of the Internet. These external variables are under the direct control of the administration of the technical colleges. So any attempt to either improve or enhance use of the Internet such as more usage for academic purposes should optimize these key controllable variables. The executives and administrators of the colleges must consider these factors so that they can serve the needs of the students within their organization. This is further supported by the fact that overall total effect of perceived usefulness is greater when compared with the total effects of perceived ease of use. This further indicates that students with more practical 
exercises and tasks are more driven to accept the technology primarily on the basis of usefulness compared to user friendliness.

The study similar to several others studies is not free from weaknesses. Several limitations of this study qualify the findings and suggest directions for future research. Most of the items are self-reported that are liable to be further response-biasness. These response errors can be minimized by some initial workshops at the college level to educate and to provide some training to the students for the research design and research objectives. The study lacks direction in assessing the problems faced by the students at the institutional level and research design could be further improved by adding more items.

Based upon the results, we therefore recommend another study based upon more variables of the students population in the technical colleges as well as in other colleges and school by adding items measure social and cultural aspects and of perceived fun/enjoyment related. This will definitely provide a better insight of the students' use of the Internet.

\section{REFERENCES}

Adams, D.A, Nelson, R.R., and Todd, P.A. 1992, "Perceived Usefulness, Ease of Use and Usage of Information Technology: A Replication”, MIS Quarterly 16(2), pp. 227-247.

Agarwal, R and Prasad, J. 1997, "The Role of Innovation Characteristics and Perceived Voluntariness in the Acceptance of Information Technology", Decision Science, 28(3), pp. 557-582.

Ajzen, I and Fishbein, M. 1980, Understanding Attitude and Predicting Social Behavior, (Prentice-Hall, Inc Englewood, Cliff, NJ).

Al-Jabri, M. I. and Al-Khaldi, A. M. 1997, "Effects of User Characteristics on Computer Attitudes among Undergraduate Business Students", Journal of End User Computing (spring), pp. 16-21.

Alsehli, F. 2000, “Internet Use within Information Science Academic Program”, Ph.D Candidate, initial findings, School of Information Studies, Florida State University.

Anonymous, 1998, Institut Teknologi Brunei, Prospectus.

Bajaj, A., and Nidumolu, S.R. 1998, "A Feed Back Model to Understand Information System Usage", Information and Management, 33, pp.213-224.

Breckler, S.J. 1990, “Application of Covariance Structural Modeling in Psychology: Cause for Concern?” Psychological Bulletin (107:2), pp.260-372.

Brown, S. and McIntyre, D. 1982, Cost and Reward of Innovations: Taking account of the teachers' viewpoint in Innovation in the Science Curriculum, (Croom Helm, London).

Brunei Darussalam Statistical Year Book., 1999 Statistical Department, Brunei Darussalam.

Campbell, D.T and Fiske, D.W. 1959, "Convergent and Discriminant Validation by the Multi-trait, Multimethod Matrix", Psychological Bulletin, 56, pp.81-105.

Chau, P.Y.K. 1996, “An Empirical Assessment of a Modified Technology Acceptance Model”, Journal of Management Information Systems, 13:2, pp. 185-204.

Chin, W., and Gopal, A. 1995, "Adoption Intention in GSS: Relative Importance of Beliefs", Data Base $(26: 2 / 3)$, pp. $42-63$

Chin, W.W., and Todd, P.A. 1995, “On the Use, Usefulness, and Ease of Use of Structural Equation Modeling in MIS Research: A Note of Caution.” MIS Quarterly (19:2), pp.237-246.

Churchill, G. A. J. 1979, “A Paradigm for Developing Better Measures of Marketing Constructs”, Journal of Marketing Research, 5, pp. 64-73.

Cronbach, L. J. 1951, "Coefficient Alpha and the Internal Structure of Test,” Psychometrika, 16, pp.297334.

Cuban, L. 1986, Teachers and Machine: The Classroom Use of Technology since 1920, (Teachers' College Press, New York).

Davis, F.D. 1989, "Perceived Usefulness, Perceived Ease of Use and User Acceptance of Information Technology", MIS Quarterly 13:3, pp. 319-340.

Davis, F. D., Bagozzi, R.P., and Warshaw, P.R. 1989, “User Acceptance of Computer Technology: A Comparison of Two Theoretical models", Management Science, 35:8, pp.982-1003.

Doty, R. 1995, “Teacher's Aid”, Internet World, 6:3, pp. 75-77.

Doyle, W., and Ponder, G.A. 1977, “The Practicality Ethic in Teacher Decision-making”, Interchange, 8:3, pp.1-12.

Falk, R.F., and Miller, N.B. 1992, A Premier for Soft Modeling, (University of Akron Press, Akron, Ohio).

Ghani, J. 1992, “Task Uncertainty and the Use of Computer Technology”, Information and Management, 22, pp.69-76.

Gaski, J.F., and Nevin, J.R. 1985, “The Differential Effects of Exercised and Unexercised Power Sources in Marketing Channel”, Journal of Marketing Research, 22, pp. 130-142. 
Gefen, D., and Straub, D.W. 1997, “Gender Difference in the Perception and Use of E-Mail: An Extension of Technology Acceptance Model”, MIS Quarterly, pp.389-399.

Goodhue, D.L, and Thompson, R.L. 1995, "Task-Technology Fit and Individual Performance”, MIS Quarterly, 19, pp.213-236.

Goodwin, N.C. 1987, "Functionality and Usability", Communication of the ACM, 30:3,

pp.229-223.

Gould, S.B. 1995, “An Intellectual Utility for Science \& Technology: The National Research \& Education Network”, Government Information Quarterly 7:4, pp.415-425.

Harris, R. 1999, “Attitudes towards End-user Computing: A Structural Equation Model”, Behavior and Information Technology, 18:2, pp.109-125.

Hayduck, L.A. 1987, Structural Equation Modeling with LISREL, (The John Hopkins University Press, Baltimore, Maryland).

Heaveside, S., Farris, E., Malitz, G.,\& Carpenter, J. 1995, “Advanced Telecommunication in US Public School k-12(E.D. Tabs, Report No NCES 95-731), (Government Printing Office, Washington DC., USA).

Igbaria, M., and Chakrabarti, A. 1990, "Computer Anxiety and Attitudes towards Microcomputer use," Behavior and Information Technology, 9:3, pp.229-241.

Igbaria, M., Guimaraes, T., and Davis, G.B. 1995, "Testing the Determinants of Micro Computer Usage via a Structural Equation Model”, Journal of Management Information Systems, 11:4, pp.87-114.

Igbaria, M., and Tan, M. 1997, "The Consequences of Information Technology Acceptance on Subsequent Individual Performance", Information and Management 32, pp. 113-121.

Igbaria, M., Pavri, F., and Huff, S. 1989, “Microcomputer Applications: An Empirical Look at Usage”, Information and Management, 16, pp.187-196.

Igbaria, M. 1992, “An Examination of Microcomputer Usage in Taiwan", Information \& Management, 22 , pp.19-28.

Igbaria, M., and Iivari, J. 1995, “The Effects of Self-efficacy on Computer”, OMEGA, 23, pp.587-605.

Igbaria, M., and Toraskar, K. 1994, "Impact of End-user Computing on the Individual: An Integrated Model”, Information Technology and People, 6, pp.271-292.

Joreskog, K.G.,and Sorbom, D. 1983, LISREL8: Structural Equation Modeling with the SIMPLIS Command Language, (Hillsdale, NJ: Lawrence Erlbaum Associates)

Kaplan,T.E., Johnson, R.W., Pearce, C.G., and George, G. 1997, “The Strategic Role of Communication Technology in Small Business: Where we are and where we should be going." American Business Review, Jan, Vol. 15(1), pp. 86-91.

Karahanna, E. 1993, "Evaluative Criteria and User Acceptance of End-user Information Technology: A Study of End-user Cognitive and Affective Processes", unpublished doctoral dissertation, University of Minnesota.

Kelloway, E.K. 1998 Using LISREL for Structural Equation Modeling, (London: Sage Publications)

Kwon, T.H., and Zmud, R.W. 1987 "Unifying the Fragmented Model of Information Systems Implementation" in critical issues in Information Systems Research, R.J. Boland Jr and R.A. Hirschheim (eds), (John Wiley \& Sons: NY).

Lee, S. and Hershberger, S. 1990, “A Simple Rule for Generating Equivalent Models in Covariance Structure Modeling”, Multivariate Behavioral Research, vol. 25, pp. 313-334.

Lou, H., Lou, W., Strong, D. 2000, "Perceived Critical Mass Effect on Groupware Acceptance", European Journal of Information Systems, vol. 9, pp. 91-103.

Lu, H.P., Gustafson, D.H. 1994, “An Empirical Study of PU and PEU on Computerized Support System Use overtime”, International Journal of Information Management, vol. 16(6), pp. 317-329.

Mathieson, K. 1991, "Predicting User Intentions: Comparing the Technology Acceptance Model with the Theory of Planned Behavior”, Information Systems Research, 2:3, pp.173-191.

Markus, M.L. 1994, "Electronic Mail as a Medium of Management Choice", Organization Science, 5:4, pp.502-527.

Palvi, S., Tung, L.L., Leng, P.T., Chin, E. S., Pei, L. W. 1995, “A Study of Internet Awareness \& Usage of two Singapore University" In the Proceedings of Pan Pacific Conference on Information Systems, Singapore, June $29^{\text {th }}$ to July $2^{\text {nd }}$, pp. $118-120$.

Pijpers, G. G. M., Bemelmans, T. M.A., Heemstra, F.J., Montfort, K.A.G.M., 2001, “Senior Executives' Use of Information Technology", Information and Software Technology, 43, pp. 959-971.

Prescott, M., and Conger, S. 1995, "Diffusion of Innovation Theory: Borrowing, Extensions and Modifications from IT Researchers", DATA BASE for Advances in Information System 26:2\&3, pp.20-41.

Rahim, M. Md., Rahman, M. N., and Seyal, A.H. 2000, "Software Piracy Among Academics: An Empirical Study in Brunei Darussalam”, Information Management and Computer Security, 8:1. pp.13-26. 
Raymond, L. Bergeron, F. 1992, "Personal DSS Success in Small Enterprise", Information and Management, 22, pp.301-328.

Rice, R.E., and Aydin, C. 1991, “Attitudes towards new Organizational Technology: Network Proximity as a Mechanism for Social Information Processing”, Administrative Science Quarterly, 36, pp.219-249.

Roger, E.M. ( $4^{\text {th }}$ Ed), 1995, Diffusion of Innovation, (The Freeman Press, New York).

Saga, V.L., and Zmud, R.W. 1993, "The Nature and Determinants of IT Acceptance, Routinization, and Infusion." in, Diffusion, Transfer, and Implementation of Information Technology: L, Levine, ed,), Software Engineering Institute, Carnegie Mellon University, Pittsburgh, PA, pp. 67-86.

Seyal, A.H., Rahim, M. Md., and Rahman, M.N. 2000, “Computer Attitudes of Non-Computing Academics: A Study of Technical Colleges in Brunei Darussalam”, Information and Management , 37, pp. 169180.

Seyal, A.H., Rahman, M.N., Yussof, H. 2001, “Academic Use of Internet”, Journal for Vocational and Technical Education \& Training, vol.2. pp.35-42

Seyal, A.H., Rahim, M. Md., and Rahman, M.N. 2002, “Determinants of Academic Use of the Internet: A Structural Equation Model”, Behavior and Information Technology, 21:1, pp. 71-86.

Soh, C., Mah, Q.Y., Gan, F.J., Chew, D., Reid, E. 1997, " The Use of the Internet for Business: The Experience of Early Adopters in Singapore”, Internet Research, 7(3), pp. 207-228.

Songan, P., and Noor, F.M. 1999, "Predictors of Internet Utilization among Students in an Institution of Higher Learning in Malaysia", In the Proceedings of Conference on Information Technology in Asia (CITA 99), Kuching 16-17 ${ }^{\text {th }}$ Sept., pp. 38-49.

Spennemann, D.H. R. 1991, “Do Techno-skeptics use on-campus E-Mail?" Campus Wide Information Systems, 14:2, pp.46-53.

Sproull, R.A. 1991, "Lesson in Electronic Mail", in Sproull, L., and Kiesler, S (eds.), Connections. New Ways of Working in the Net Work, (MIT Press, Cambridge, MA).

Stelzl, I. 1986," "Changing a Causal Hypothesis Without Changing the Fit: Some Rules for Generating Equivalent Path Models, Multivariate Behavioral Research 21, pp.309-331.

Stix, G. 1994, "The Speed of Write", Scientific American, (Dec), pp.72-77.

Straub, D.W., Limayem, M., Karahanna-Evaristo, E., 1995, "Measuring Information System Usage: Implications for theory Testing”, Management Science, 41:8, pp.1328-1342.

Straub, D.W., Keil, M., and Brenner, W. 1997, "Testing the Technology Acceptance Model across Cultures: A Three Country Study", Information \& Management, 33. pp. 1-11.

Szanja, B. 1994, "Software Evaluation and Choice: Predictive Validation of the Technology Acceptance Instrument", MIS Quarterly, 18(3).

Szanja, B., 1996, "Empirical Evaluation of the Revised Technology Acceptance Model." Management Science, 42(1), pp.85-92.

Thompson, R.L, Higgins, C.A., Howell, J. M. 1991, "Personal Computing: Toward a Conceptual Model of Utilization", MIS Quarterly, 15:1, pp. 125-143.

Triandis, H.C. 1971, Attitude and Attitude Change, (NY: John Wiley)

Turner, R., Zheng, W. 1998, "Staff Use of the Internet", In the proceedings of 15th Pan Pacific Conference in Seoul.

Veiga, J.F., and Floyd, S. 2001, "Towards Modeling the Effects of National Culture on IT Implementation and Acceptance", Journal of Information Technology, vol. 16, pp. 145-158.

Yaverbaum, G.S. 1988, "Critical Factors in the User Environment: An Experimental Study of Users, Organization and Tasks", MIS Quarterly, 12:1, pp.75-85.

Yang, H-D., Choi, I-Y. 2001 "Revisiting Technology Acceptance Model With Social Influence Factors", In the Electronic Proceedings of PACIS 2001, Seoul, Korea., pp. 509-523.

Zikmund, W.G. 1984, Business Research Methods, (USA: Dryden Press). 